\title{
Why China Still Faces the High Risk of Criminal Injustices?
}

\author{
Jiang Na and Han Rong* \\ Department of Criminal Law Science, China
}

*Corresponding author: Jiang $\mathrm{Na}$, College for Criminal Law Science, China.

Received Date: February 11, 2019

Published Date: February 21, 2019

\section{Introduction}

Although China has raised more procedures for protecting rights of suspects or the accused, it is still difficult for the judiciary to independently and impartially exercise its power in excluding the illegally obtained evidence and acquitting the accused by law. The high risk of wrongful convictions remains, mainly due to inadequate restriction on power abuses, more attention paid to crime control than to human rights protection and undue interference with courts independence in law or in practice.

\section{Inadequate Restriction on Power Abuses}

Mutual restraints among judicial, prosecutorial and police powers set down by law are flawed. There is no way for them to both cooperate with and restrain one another in the criminal process. They often abuse powers to only cooperate with one another to convict the accused for crime control. Given the police's expansive power, prosecutorial organs have little chance to effectively correct police errors when supervising investigations. Prosecutors and judges hardly exclude all tainted evidence from use, given the obstacles to checking evidence submitted by police officers. Also, major cases are still supposed to be decided by trial committees that do not attend court hearings, rather than judges. These shortfalls cannot help China transit towards the trial-based process but lead to a low rate of acquittals.

As showed from cases with the illegally obtained evidence successfully excluded, any forms of such evidence relate to tortured confession or its potential use by police officers, whereas prosecutors or judges often apply the exclusionary rules in a narrow sense in order to control crime with the police. Clearly, none of the three institutions can effectively exclude all of false and coerced confessions. Combined with inadequate restrains on their power, it is very unlikely to prevent wrongful convictions resulting from suspected torture and to protect suspects or the accused from widespread rights abuses in the criminal process. The typical examples on official understanding of such rules are as follows:
In LI Changfa's robbery case, the local court in H Province decided not to exclude his application for excluding the illegally obtained evidence in 2014. Although the accused LI said that his first confession was forced by police torture, like pouring cold water, and later confessions resulted from his fear of continued torture, the prosecution regarded the third confession as his voluntary expression of his true intention without torture then for two reasons. They are that the accused cannot provide any clues or evidence on police torture, and that his third confession made in a detention center where no torture involved, is consistent with the contents of his previous statements on the guilt, and with the details in victims' confirmation. On such reasoning, both the prosecution and the local court held that no evidence supports the accused's defense for his tortured confession. The court even deems the prosecution's explanations on the legitimacy of means, by which the police extort evidence, to be objective and credible, so as not to exclude all of tortured confessions based on the above explanations.

In fact, the police, prosecutors and courts jointly undertake the legal duty to exclude the illegally obtained evidence at any stage of the criminal process. Also, tortured suspects only need to provide clues on torture, but not bear the burden of proof that should be on the prosecution's shoulder by law. In the above case, the prosecution never took measures to collect evidence of suspected torture but shifted his burden of proof to the accused LI who claimed police torturing him in order to use his false confessions for conviction or hide police errors against justice. The court further failed to examine or collect the evidence, but directly supported police evidence and prosecutor's non-exclusion, based on the assumption that later evidence collected by legal means justifies other or all evidence's legitimacy. In a similar case of ZHOU's stealing, covering up and concealing proceeds of crime in Shanghai in 2014, the accused showed injuries on his nose and mouth skin resulting from investigators' beating in the first interrogation, to prosecutors and 
the court, in application for excluding tortured confessions. As a response, the prosecution provided the court with simultaneous audio and video recordings of interrogating the accused ZHOU for the second time, when newly changed investigators different from the first group made the recordings of the second interrogation. According to them, police investigators did not torture the accused in collecting oral confessions from him. Also, the prosecution proved in court that ZHOU confessed at the stage of examination for prosecution without any pressure from torture, so that prosecutors deemed ZHOU's application for excluding tortured confessions in his first interrogation to be not acceptable. Although the accused applied for excluding tortured confessions in his initial interrogation, rather than later confessions, the court refused to exclude all of his confessions due to no torture imposed on the accused after the first interrogation, exactly as the prosecution held.

\section{Crime Control}

Obviously, the police still highly depend on torture to extort confessions from suspects and thus cannot exclude the illegally obtained evidence by themselves as the exclusionary rules expected in law. They actually would rather wrongly convict the innocent in order to achieve the goal of crime control, than acquit the accused in order to better protect their human rights as required by law.

As showed in the above cases, once with evidence to prove that confessions were collected by legal means without the use of torture, the prosecution and court would rather cooperate with the police to justify any collecting means with a legal cover to be lawful, than actually fulfill their legal duty to exclude the illegally obtained evidence. In official understandings, the scope of the illegally obtained evidence is limited to direct evidence, and even wrongly narrowed down to such evidence that cannot get a legal cover by any means in practice. Their illogic reasoning on evidence exclusion also indicates a serious lack of effective restrictions on power abuses at each stage of the criminal process, which cannot prevent but produce more injustices.

\section{Undue Interference with Courts Independence}

In addition, Chinese courts are not totally independent from powerful authorities, not to mention its judges' independence. In contentious cases, particularly under great pressure from petitions made by victims' relatives or from public opinions, judges would rather convict the accused who was tortured by police officers and impose a lighter punishment than acquit him or her even with adequate defense. Under the institutional environment of more attention paid to social stability than to the proper enforcement of law, it is unlikely to prevent power abuses from leading to torture or ineffective defense or to reduce public opinions' undue interference with courts' impartial judgements. The more cooperation between the police, prosecutor and courts in the criminal process for their goal of crime control, the less justice or rights protection any reforms to prevent wrongful conviction would end with. As demonstrated from the above case studies and the latest data, tortured confession or ineffective defense counsel is not rare and even becomes widespread without effective restraints on police power or remedies for power abuses in China's practice. Even with counsel's adequate defense for the accused at trial, many courts still follow prosecutors and police investigators to admit tortured confession as evidence, rather than fully examine and consider evidence of innocence in order to exonerate the innocent. The danger resulting from the confessions or ineffective defense in the Chinese context is so grave as to likely defeat the expected aims of ensuring justice and protecting human rights.

Together with the limited scope of the illegally obtained evidence in its official understanding and usual practice, tortured confessions and ineffective defense also become common factors contributing to wrongful convictions which occurred after post-SHE or post-ZHAO reforms over the recent decade. Their persistence is clearly detrimental to criminal justice and human rights, as the underlying aim and purpose of the movement for preventing wrongful convictions. In fact, the actual implementation of the 2012 CPL and new measures are still poor in reality. Progress in the movement is far from satisfactory and does not meet the needs of criminal justice. In this sense, the latest developments could be compared to one step forward and one step back as slow progress in China's long march towards justice.

\section{Conclusion}

In order to shorten its long march, further substantive reforms needed to be taken. Given that the current mechanism for preventing wrongful convictions still has considerable deficiencies, Chinese authorities should proceed to establish a complete framework for preventing wrongful conviction that can mend the pitfalls in the justice system. Specifically, it should contain mechanisms for evidence investigation, evidence examination and evidence exclusion, as well as a comprehensive set of rules regulating the trial-based process. It should ensure that trials are independent from outside interference and at the center of the criminal process. All institutional obstacles need to be removed in order to give defense counsels and independent courts to fully play their roles in preventing wrongful convictions.

\section{Acknowledgement}

None.

\section{Conflict of Interest}

No conflict of interest. 